\title{
LIPID AND SILVER NANOPARTICLES GELS FORMULATION OF TEMPEH EXTRACT
}

\author{
Felicia Satya Christania, Rini Dwiastuti*), Sri Hartati Yuliani
}

S2 Study Program, Faculty of Pharmacy, Sanata Dharma University, Yogyakarta, Indonesia

Received August 10, 2019; Accepted November 21, 2019

\begin{abstract}
Tempeh extract is used in this study as an active ingredient in lipid nanoparticles and reductant in silver nanoparticles because tempeh is an authentic Indonesian food ingredient and is known to have the main content of isoflavones. Gel preparations were chosen to increase the acceptability and stability of lipid and silver nanoparticles. This research aim is to formulate lipid nanoparticle gel formulations with tempeh extract as active substances and silver nanoparticle gel formulations with tempeh extract as bioreduction. Lipid nanoparticles were made from soy lecithin phospholipids by heating at $60^{\circ} \mathrm{C}$ and sonication method for 30 minutes then the tempeh extract was added just before sonication. Silver nanoparticles were made by adding tempeh extract to $\mathrm{AgNO}_{3}$ solution at $90^{\circ} \mathrm{C}$ for 30 minutes. The average particle size of tempeh extract lipid nanoparticles was $130.03 \mathrm{~nm}$ and silver nanoparticle was $94.76 \mathrm{~nm}$. The average viscosity of tempeh extract lipid nanoparticles gel was 4.02 d.Pa.s and silver nanoparticles was 4.22 d.Pa.s. The average spreadability of tempeh extract lipid nanoparticles gel was $4.37 \mathrm{~cm}$ and silver nanoparticles is $4.05 \mathrm{~cm}$. The average $\mathrm{pH}$ value of tempeh extract lipid nanoparticles was 7.70 and silver nanoparticles was 7.33.
\end{abstract}

Keywords: gel; lipid nanoparticles; particle size; silver nanoparticles; tempeh extract

\section{INTRODUCTION}

Nanoparticles are one of the technologies developed to increase the effectiveness of drug delivery (Latarissa 2017). Nanoparticles have the advantage to penetrate the space between cells and it able to increase the surface area contact. Nano-sized particles have unique physical properties because they can be combined with a variety of technologies. They are expected to produce a more effective drug delivery system (Martien et al. 2012). Nanoparticles can be made with specific colloidal formation systems, and one example is liposomes that are made using soy lecithin (Dwiastuti, Noegrohati, and Istyastono 2016). Another method for preparation of nanoparticles is to use metals then reduced with specific materials to form nanoparticles, one example is silver nanoparticles using $\mathrm{AgNO}_{3}$ solution added with specific reducing agents (Sileikaite et al. 2006).
Lipid nanoparticles are made through the formation of soy lecithin phospholipid nanoliposomes by heating and sonication methods (Dwiastuti, Noegrohati, Istyastono, et al. 2016). Soy lecithin contains unsaturated fatty acids. It has excellent penetration in the skin and high compatibility in the body (Dwiastuti, Noegrohati, Istyastono, et al. 2016). Lipid nanoparticles can combine lipophilic and hydrophilic properties in preparations (Dwinna 2010). Silver nanoparticles are produced through a method of mixing $\mathrm{AgNO}_{3}$ solution (Tatang Wahyuni, Doni Sugiyama 2011) and specific bioreduction (Muliadi et al. 2015). Bioreduction are extracts of natural substances that can act as reductant (Jain D et al. 2009). The success of silver nanoparticle formation can be known shortly after manufacture by measuring the maximum wavelength using UV-Vis spectrophotometry (Jain, Arora, et al. 2009). 
Tempeh extract on lipid nanoparticles is used as an active substance, while tempeh extract on silver nanoparticles is used as a bioreduction. Tempeh extract is known to have the main content of isoflavones derived from flavonoid compounds that function as wound healers (Park et al. 2011). In this research, lipid nanoparticles and silver nanoparticles were formulated to review the physical properties between the two preparations. Lipid nanoparticles were developed as topical preparations because they have good penetration ability (zur Mühlen et al. 1998) (Jafar et al. 2015). Silver nanoparticles were developed as topical preparations because they have the antibacterial ability (Ariyanta 2014). It can be developed in preparations for wound healing preparations (Ariyanta 2014) and anti-acne (Septyarin 2017). The development of these two preparations needs to be reviewed for particle size and physical properties as seen from the parameters of viscosity, dispersion, and $\mathrm{pH}$. This preparation is expected to be a choice of drug dosage forms, especially topical preparations for various expected pharmacological effects, for example: wound healing and anti-acne preparations. Therefore, this study aims to formulate lipid nanoparticle gel formulations with tempeh extract as active substances and silver nanoparticle gel formulations with tempeh extract as bioreduction with a review of physical properties and particle size.

\section{METHODS}

\section{Materials}

The material used in this study were: soybean lecithin (Sigma-Aldrich), distilled water, tempeh with three days fermentation under the brand name "Muchlar", $\mathrm{AgNO}_{3}$, Carbopol, Propylenglycol, Triethanolamin, and Glycerin are obtained from "Bratachem".

\section{Instrumentation}

Instruments used in this study are, particle size analyzer (HORIBA Scientific, Japan), Spectrophotometer UV-VIS (Shimadzu, JAPAN), pH meter, and Viscosimeter Rheosys (Model: Merlin VR).

\section{Preparation of Tempeh Extract}

The tempeh extract was prepared by tempeh with three days fermentation under the brand name "Muchlar". Tempeh was cut $5 \mathrm{~cm}$ long and $6.5 \mathrm{~cm}$ wide and $1 \mathrm{~cm}$ thick. Tempeh extract was made with the ratio of tempeh and aquadest which is 1: 2 . Three hundred grams of tempeh was added into $600 \mathrm{~mL}$ of distilled water, then heated to a temperature of $90^{\circ} \mathrm{C}$. Maintained the temperature remained $90^{\circ} \mathrm{C}$ for 30 minutes then the extract cooled to a temperature $30^{\circ} \mathrm{C}$ then filter with filter paper.

\section{Preparation of Lipid Nanoparticles of Tempeh Extract as the Active Substances}

Lipid nanoparticles were made by weighing soybean lecithin by 12 grams and then minimized by mortar and stamper. The refined soy lecithin was then homogeneously dispersed in $200 \mathrm{~mL}$ of aquabidest at $60^{\circ} \mathrm{C}$. The soy lecithin dispersion was then blended at high speed for sixty seconds. The soy lecithin suspension was maintained at $60^{\circ} \mathrm{C}$ and then homogenized with ultraturax for one minute on 4 scale. Furthermore, soy lecithin suspension was put in the bath sonicator together with tempeh extract as much as 80 $\mathrm{mL}$. The sonicator bath is set to a temperature of $60^{\circ} \mathrm{C}$ for 30 minutes (Dwiastuti, Noegrohati, Istyastono, et al. 2016).

\section{Preparation of Silver Nanoparticles Using Tempeh Extract as Bioreduction}

Silver nanoparticles were made by weighing 0.034 grams of silver nitrate $\left(\mathrm{AgNO}_{3}\right)$ in $200 \mathrm{~mL}$ aquabidest $(1 \mathrm{mM})$ silver nitrate solution. The silver nitrate solution was heated to a temperature of $90^{\circ} \mathrm{C}$. Then it was added with tempeh extract $80 \mathrm{~mL}$ and kept at $90^{\circ} \mathrm{C}$ while stirring $600 \mathrm{rpm}$ for 30 minutes (Ramadon and Mun'im 2016; Ariyanta 2014).

\section{Preparation of Gel and Physical Properties Testing}

The preparation of this formula began with the swelling of carbopol. It was prepared in $100 \mathrm{~mL}$ lipid nanoparticles or $100 \mathrm{~mL}$ silver nanoparticles with 3 grams of carbopol for 24 hours. Then, 3 grams of carbopol $3 \% \mathrm{w} / \mathrm{v}$ as much as 50 grams and added TEA to the 
mortar and stirred until homogeneous for about 5 minutes. Next, put the mixture of carbopol and TEA into the blender and add propylene glycol and glycerin and mixing or three minutes at low speed.

Table I. Gel Formula of Lipid and Siver Nanoparticles Gel

\begin{tabular}{cc}
\hline \multicolumn{1}{c}{ Ingredients } & Formula \\
\hline $\mathrm{R} /$ Carbopol 3\% b/v (gram) & 50 \\
\hline Propyleneglycol (gram) & 30 \\
\hline Glycerin (gram) & 60 \\
\hline Triethanolamin (TEA) (gram) & 2,4 \\
\hline
\end{tabular}

Scattering Test. The scatter power test was carried out 24 hours after manufacture by putted one gram of gel and placed in the middle of a large round glass. On top of the gel was placed another round glass and ballast with a total weight of 125 grams then allowed to stand for one minute and note the spread diameter. Viscosity Test. The viscosity test was carried out 24 hours after preparing the gel using the Rheosys cone and plate Merlin VR model. $p H$ test. The $\mathrm{pH}$ test carried out 24 hours after the gel prepared using a $\mathrm{pH}$-meter. The $\mathrm{pH}$ test began with putted one gram of gel and then dissolved it in $10 \mathrm{~mL}$ aquadest. Furthermore, the $\mathrm{pH}$ meter inserted into the aquadest and then putted into a gel then the $\mathrm{pH}$ meter will show the $\mathrm{pH}$ value.

\section{Wavelength of Silver Nanoparticles.}

Measurement of the maximum wavelength is one of the initial steps to determine silver nanoparticles. The indicator of silver nanoparticles is the wavelength with maximum absorbance in the range of 400-450 nm (Ariyanta, 2014; Ayu 2015).

\section{Particles Size of Lipid Nanoparticles and Silver Nanoparticles.}

This measurement is done by conducting a DLS particle size analyzer (Horiba SZ 100, Japan).

\section{Data analysis}

Particle size data and physical properties test results obtained in this study were then performed statistical tests with the $R$ computational statistical program. The $\mathrm{T}$ test used to find out whether there are significant differences in physical properties results between lipid nanoparticles with silver nanoparticles preparations.

\section{RESULTS AND DISCUSSION}

Tempeh extract contains a lot of isoflavones with a function as a wound healing (Danciu et al. 2012). Tempeh extract was prepared with water solvent so that the tempeh extract can be used as a bioreduction in the formation of silver nanoparticles. One of the bioreduction requirements in the formation of silver nanoparticles is a water-soluble extract. That is expected to dissolve and react with $\mathrm{AgNO}_{3}$ solution. While in the addition of lipid nanoparticles, tempeh extract functions as an active substance.

\section{Physical Appearance of Tempeh Extract Lipid Nanoparticles and Tempeh Extract Silver Nanoparticles}

The description of lipid nanoparticle was a turbid white color and unique smelled of soy lecithin. The silver nanoparticle preparations had a clear-reddish-brown and unique smelled of tempeh extract. Clear-reddish-brown in the aqueous solution formed from excitation. The reduction of silver ion causes it; there are indicated the formation of silver nanoparticles (Jain, Daima, et al. 2009). This physical appearance of difference nanoparticle preparation and gel nanoparticle is presented in Figure 1 and 2.

The Particle Size of Tempeh Extract Lipid Nanoparticle and Tempeh Extract Silver Nanoparticles

The lipid nanoparticles formation can be known after the Particle Size Analyzer (PSA) test have been done. The formation of silver nanoparticles can be recognized immediately by measuring the maximum wavelength using UV Vis spectrophotometer. If the wavelength is between $400-450 \mathrm{~nm}$, it means that silver nanoparticles are known (Maharini et al. 2017). This is one of the advantages of silver nanoparticles compared to lipid nanoparticles, namely the success of the preparation formulation can be known after manufacture. 
In this study, wavelength measurements were made after 24 hours of storage. The average wavelength measurements of silver nanoparticles with three replications after 24 hours of storage at room temperature were obtained $406 \mathrm{~nm}$. The results of these wavelength measurements indicate that silver nanoparticles can be formed the extract of tempeh as bioreduction at a temperature of $90^{\circ} \mathrm{C}$ and 30 minutes (Sari Purwo Ismaya et al. 2017).

PSA test was conducted to determine the size of lipid nanoparticles (Dwiastuti, Noegrohati, Istyastono, et al. 2016) and silver nanoparticles. PSA test results are shown in Table II.

The measurement results in Table II showed that the silver nanoparticle formula could produce particle sizes less than $100 \mathrm{~nm}$, while the lipid nanoparticle formulas produce sizes more than $100 \mathrm{~nm}$. Tempeh Extract in lipid nanoparticle as an active substance make colloidal dispersion could not be form completely so that affect particles size. Tempeh extract in silver nanoparticle will act as bioreductor in silver nitrate and could produce nanoparticle. Analysis with T-test at 95\% confidence level obtained p-value of 0.21 . Thus the average particle size of tempeh extract lipid nanoparticles was the same as the average particle size of tempeh extract silver nanoparticles and not significantly different. This phenomena could be happen because in silver nanoparticle extract tempeh will initiate reduction reaction of silver nitrate and reduce particle size, but in lipid nanoparticle, particle will be reduce by the reaction of colloidal dispersion from soy lecithin (Dwiastuti, Noegrohati, Istyastono, et al. 2016).
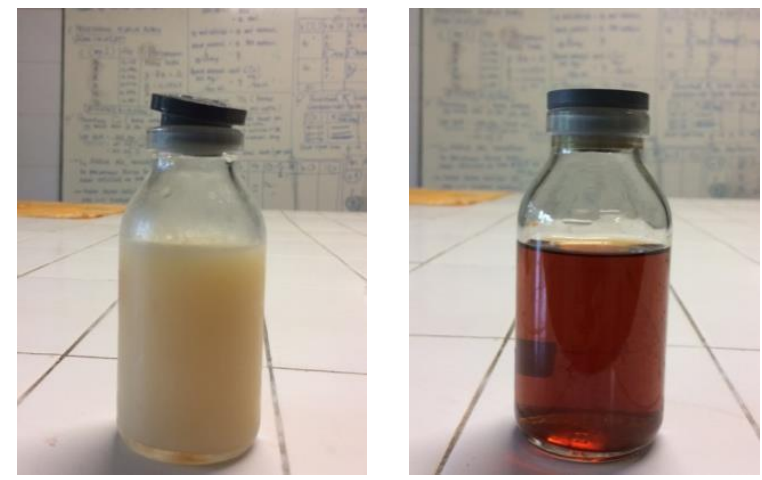

Figure 1. Tempeh extract nanoparticle preparation of lipid nanoparticles (a) and silver nanoparticles (b)

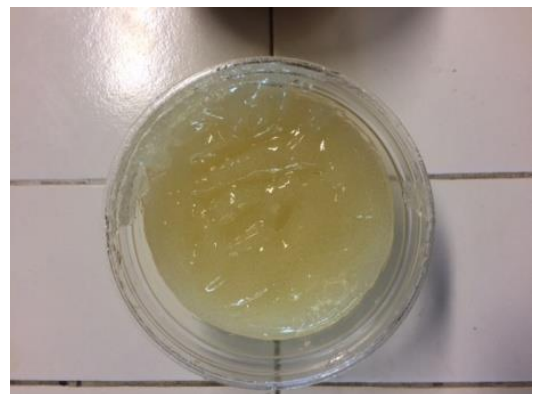

(a)

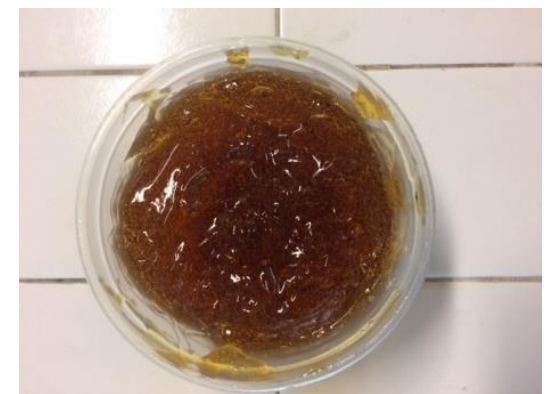

(b)

Figure 2. Gel nanoparticle of lipid nanoparticle (a) and silver nanoparticle (b) 
Table II. Particle Size Analyzer (PSA) result of Lipid and Silver Nanoparticles with Tempeh Extract

\begin{tabular}{lcc}
\hline \multicolumn{1}{c}{ Replication } & $\begin{array}{c}\text { Tempeh Extract } \\
\text { Nanoparticle Lipid }(\mathrm{nm})\end{array}$ & $\begin{array}{c}\text { Tempeh Extract Silver } \\
\text { Nanoparticles }(\mathrm{nm})\end{array}$ \\
\hline Replication 1 & 129,00 & 128,10 \\
\hline Replication 2 & 124,00 & 87,00 \\
\hline Replication 3 & 124,20 & 69,20 \\
\hline Average & $130,03 \pm 6,41$ & $94,76 \pm 30,20$ \\
\hline
\end{tabular}

Table III. Viscosity, Spread ability, and pH Value Result of Lipid and Silver Nanoparticles

\begin{tabular}{lcccc}
\hline \multicolumn{1}{c}{ Parameter } & $\begin{array}{c}\text { Lipid } \\
\text { Nanoparticle }\end{array}$ & $\begin{array}{c}\text { Silver } \\
\text { Nanoparticle }\end{array}$ & $\begin{array}{c}p \\
\text { value }\end{array}$ & Statistical Result \\
\hline Viscosity (d.Pa.s) & $4,02 \pm 0,20$ & $4,22 \pm 0,33$ & 0,59 & Not Significantly Different \\
\hline Spread ability $(\mathrm{cm})$ & $4,37 \pm 0,11$ & $4,05 \pm 0,02$ & 0,99 & Not Significantly Different \\
\hline pH & $7,70 \pm 0,10$ & $7,33 \pm 0,05$ & 0,98 & Not Significantly Different \\
\hline
\end{tabular}

\section{Physical Properties of Tempeh Extract Lipid Nanoparticles Gel and Tempeh Extract Silver Nanoparticle Gel Preparations}

Preparation of tempeh extract lipid nanoparticles and tempeh extract silver nanoparticles were tested for physical properties with parameters including: viscosity, spread ability, and $\mathrm{pH}$ value. Physical test results of lipid nanoparticle gel and silver nanoparticle gel preparations showed physical properties test results with $\mathrm{pH}$ parameters. The results of the physical properties test were followed by an analysis of the T-test with a 95\% confidence level to see differences in physical properties of the two preparations.

The results of the viscosity testing (Table III) after 24 hours of preparation of lipid nanoparticles and tempeh extracts of silver nanoparticles indicated no different results. This result is strengthened by the results of statistical tests using the T-test. The analytical results showed p-value is 0,59 so that it can be said that the viscosity of the two preparations that are not significantly different. Viscosity is influenced by the carbopol composition, because carbopol acts as gelling agent that will form gel-forming matrix (Maheswara 2008). The carbopol composition of Lipid Nanoparticle Gel and Silver Nanoparticle Gel have same composition, thus the result of the viscosity testing are not significantly different
The similar analysis results were also found in the spread ability (Table III) and $\mathrm{pH}$ response of lipid nanoparticle gel and tempeh extract silver nanoparticles. Statistical tests with the T-test obtained that the $p$ value of the spread ability test is 0.99 and the p-value of the $\mathrm{pH}$ test is 0.98 . It can be explained that the spread ability and $\mathrm{pH}$ of the preparations resulting from the formulation of lipid nanoparticles and silver nanoparticles of tempeh extract have no significantly different results. This result can be obtained because the amount of gelling agent and humectant used for the preparation of gel nanoparticle lipid and silver nanoparticle gel preparations uses the same amount. The physical properties of gel preparation are influenced by the gelling agent and humectants used in the formulation. Carbopol act as gelling agent and Propylene glycol act as humectant. Gelling agent will form gel-forming matrix. Humectant will maintain the stability of dosage form by absorbing moisture from the environment and reducing the evaporation of water from the preparation. Because of that, spread ability and viscosity will influence dominantly by carbopol and propylene glycol will influence the stability of dosage form (Maheswara 2008).

\section{CONCLUSIONS}

Lipid and silver nanoparticles of tempeh extract can be formulated and the average 
particle size of lipid nanoparticles was 130.03 $\mathrm{nm}$ and silver nanoparticle was $94.76 \mathrm{~nm}$. The average viscosity of lipid nanoparticles gel was 4.02 d.Pa.s and silver nanoparticles was 4.22 d.Pa.s.. The average spreadability of lipid nanoparticles gel was $4.37 \mathrm{~cm}$ and silver nanoparticles is $4.05 \mathrm{~cm}$. The average $\mathrm{pH}$ value of tempeh extract lipid nanoparticles was 7.70 and silver nanoparticles was 7.33.

\section{ACKNOWLEDGEMENT}

Thank you to the Ministry of Research and Technology of Higher Education for funding through the Master Thesis Research Grant with contract letter no: 029/Penel./ LPPMUSD/IV/2019. Thank you to Maria Yolanda Intansari, Joshua Hengky Purwanto, Anastasia Peni Hera, Eunike Meilani, and Mia Priliana Forever who helped laboratory technical.

\section{REFERENCES}

Ariyanta, H.A., 2014. Preparasi Nanopartikel Perak dengan Metode Reduksi dan Aplikasinya sebagai Antibakteri Penyebab Luka Infeksi. Indonesian Journal of Chemical Science, 10 (1), 3642.

Ayu, H., 2015. Kinetika Sintesis Nanopartikel Perak dari Larutan AgNO3 dengan Menggunakan Ekstrak Bungkil Biji Jarak Pagar sebagai Reduktor. Sekolah Pascasarjana Institut Pertanian Bogor.

Danciu, C., Soica, C., Csanyi, E., Ambrus, R., Feflea, S., and Peev, C., 2012. Changes in the anti-inflammatory activity of soy isoflavonoid genistein versus genistein incorporated in two types of cyclodextrin derivatives Changes in the antiinflammatory activity of soy isoflavonoid genistein versus genistein incorporated in two typ. Chemistry Central Journal, 6 (1), 1.

Dwiastuti, R., Noegrohati, S., and Istyastono, E.P., 2016. Formulation and Physical Properties Observations of Soy Lecithin Liposome Containing 4- $\mathrm{n}$ Butylresorcinol. American Institute of Physics, 160005 (1755), 1-5.

Dwiastuti, R., Noegrohati, S., Istyastono, E.P., and Marchaban, 2016. Metode
Pemanasan dan Sonikasi Menghasilkan Nanoliposom dari Fosfolipid Lesitin Kedelai (Soy Lecithin). Jurnal Farmasi Sains dan Komunitas, 13 (1), 23-27.

Dwinna, R., 2010. Lemak Padat Nanopartikel; Sintesis dan Aplikasi. Jurnal Kimia dan Kemasan, 32 (1), 27-33.

Jafar, G., Darijanto, S.T., and Mauludin, R., 2015. Formulasi Solid Lipid Nanoparticle Ceramide. Jurnal Pharmascience, 2 (2), 80-87.

Jain, D., Daima, H.K., Kachhwaha, S., and Kothari, S.L., 2009. Synthesis of PlantMediated Silver Nanoparticles Using Papaya Fruit Extract and Evaluation of Their Anti Microbial Activities. Digest Journal of Nanomaterials and Biostructures, 4 (3), 557-563.

Jain D, Daima HK, Kachhwala S, and Kothari SL, 2009. Synthesis of plant-mediated silver nanoparticles using papaya fruit extract and evaluation of their anti microbial activities. Digest Journal of Nanomaterials and Biostructures , 4 (3), 557-563.

Jain, J., Arora, S., Rajwade, J.M., Omray, P., Khandelwal, S., and Paknikar, K.M., 2009. Silver nanoparticles in therapeutics: Development of an antimicrobial gel formulation for topical use. Molecular Pharmaceutics, 6 (5), 1388-1401.

Latarissa, I.R., 2017. Review Artikel: Aplikasi Teknologi Nanopartikel pada Sediaan Kosmetik. Farmaka, 4 (November 2017), $1-15$.

Maharini, I., Wigati, S., and Utami, D.T., 2017. Formulasi Nanopartikel Ekstrak Buah Naga (Hylocereus Polyrhizus) Sebagai Zat Warna Sediaan Lipstik. Chempublish Journal, 2 (1), 38-43.

Maheswara, L., 2008. Optimasi Formula Gel Anti-Ageing Ekstrak Etil Asetat Isoflavon Tempe dengan Carbopol 940 sebagai Gelling Agent dan Propilenglikol sebagai Humectant : Aplikasi Desain Faktorial.

Martien, R., Adhyatmika, Irianto, I.D.K., Farida, V., and Sari, D.P., 2012. Perkembangan Teknologi Nanopartikel sebagai Sistem Penghantaran Obat. 
Farmaseutik Universitas Gadjah Mada, 8 (1), 133-144.

zur Mühlen, A., Schwarz, C., and Mehnert, W., 1998. Solid lipid nanoparticles (SLN) for controlled drug delivery--drug release and release mechanism. European journal of pharmaceutics and biopharmaceutics: official journal of Arbeitsgemeinschaft fur Pharmazeutische Verfahrenstechnik e.V, 45 (2), 149-155.

Muliadi, Arief, A., and Khadijah, 2015. Biosintensis Nanopartikel Logam Menggunakan Media Ekstrak Tanaman. Jurnal Farmasi Fakultas Kedokteran dan Ilmu Kesehatan UIN Alauddin, 3 (2), 64 72.

Park, E., Lee, S.M., Jung, I.K., Lim, Y., and Kim, J.H., 2011. Effects of genistein on early-stage cutaneous wound healing. Biochemical and Biophysical Research Communications, 410 (3), 514-519.

Ramadon, D. and Mun'im, A., 2016. Pemanfaatan Nanoteknologi dalam Sistem Penghantaran Obat Baru untuk
Produk Bahan Alam. Jurnal Ilmu Kefarmasian Indonesia, 14 (2) (2), 118127.

Sari Purwo Ismaya, M. Lutfi Firdaus, and Elvia Rina, 2017. Pembuatan Nanopartikel Perak dengan Bioreduktor Ekstrak Buah Muntingia calabura L untuk Analisis Logam Merkuri. Jurnal Pendidikan dan Ilmu Kimia, 1 (1), 20-26. Septyarin, I.P., 2017. Uji Aktivitas Antibakteri Nanopartikel Perak Terhadap Mutu Sediaan Farmasi Krim Jerawat. Journal of Chemistry Universitas Negeri Surabaya, 6 (1), 59-63.

Sileikaite, A., Prosycevas, I., Puiso, J., Juraitis, A., and Guobiene, A., 2006. Analysis of Silver Nanoparticles Produced by Chemical Reduction of Silver Salt Solution. Material Science, 12 (4), 287-291.

Tatang Wahyuni, Doni Sugiyama, Q.H., 2011. Sintesis Nanopartikel Perak Dan Uji Aktivitasnya. Arena Tekstil, 26 (1), 5560. 